\title{
Impact of SMEs on Employment in Textile Industry of Pakistan
}

\author{
Dr. Anwar Ali Shah G. Syed \\ Dean Faculty of Commerce \& Business, University of Sindh, Jamshoro, Pakistan \\ E-mail: dr_anwar_shah@yahoo.com \\ Dr. Naimat Shah \\ Assistant Professor, Deptt: of Public Administration, University of Sindh, Jamshoro, Pakistan \\ Dr. Khalid Hussain Shaikh \\ Associate Professor, Institute of Commerce, University of Sindh, Jamshoro, Pakistan \\ Muhammad Munir Ahmadani \\ $\mathrm{PhD}$ research Scholar, IBA, University of Sindh, Jamshoro, Pakistan
}

Faiz. M. Shaikh

Assistant Professor, SZABAC, Dokri, Larkana, Sindh, Pakistan

E-mail: faizmuhammed_2000@yahoo.com

Received: October 9, 2011

Accepted: November 27, 2011

Published: April 1, 2012

doi:10.5539/ass.v8n4p131

URL: http://dx.doi.org/10.5539/ass.v8n4p131

\begin{abstract}
This research investigates the impact of Small \& Medium Enterprises on Employment in textile industry. Data were collected from 100 respondents from 30 organizations by using simple random technique. A structural questionnaire was developed to get reliability of the Data. Data were analyzed by using SPSS-18 version. It was revealed that SMEs are the major source of foreign exchange earnings, SMEs have a major contribution in Pakistan's GDP, A known feature of SME sector is its ability to create jobs, SMEs maintain the poverty alleviation activities through creating employment, SMEs assist in fostering a self-help and entrepreneurial culture, SMEs boost up an entrepreneurial strength which puts forward flexibility in the economy, SMEs are more capable in resource allocation as compared to large scale industries, SMEs in general consider employees as their most important resources, SMEs are pioneer in developing new products and services and finally SMEs are in general very quality minded in the products and services they provide.
\end{abstract}

Keywords: SMEs, Employment, Sector, Sindh

\section{Introduction}

SMEs on creation of employment, section three investigates the importance and significance of SMEs, section four addresses behavior of employer/manager in official and un-official matters with the employees, section five explores the appointment procedure in SMEs, section six discovers the contribution of SMEs to private sector employment section seven find out the contribution of SMEs to government sector employment, section eight highlights on the growth of SMEs in Sindh, section nine determines the performance/improvements of SMEs in textile industry of Pakistan during last five years, section ten assesses the role of textile industry of Pakistan in creation of job opportunities in the country, section eleven evaluates the fundamental role of textile sector in the exports of Pakistan, section twelve inspects the performance of textile sector in the development of the manufacturing sector in Pakistan and finally section thirteen observes the contribution of SMEs in employment of Pakistan. 


\section{Literature Review}

SMEs have historically taken as an significant part in contributing to economic progress of many countries around the world (Kongolo, 2010). There is no growth when the advantages of economic improvements are utilized only by a small number of people, whereas the greater parts are being expelled (Todaro and Smith, 2003). The unconstructive effects of current economic turn down have seriously influenced the socio-economic conditions of many people universally. As a reply to these negative conditions, it is necessary that the small, medium and large entrepreneurs improve their employment formation capabilities (Barakat, 2001). It was also pointed out by the Advani (1997) that from the socio-economic development point of view, SMEs provide a variety of benefits. A well-supported and enhanced small business sector is likely to continue contributing to the economic development process in the same way as a large business (Abraham, 2003). One of the noteworthy distinctiveness of a prosperous and emergent economy is a booming and blooming small and medium enterprises (SMEs) sector (Feeney and Riding, 1997).

Feeney and Riding (1997) further argued that small and medium enterprises play an important role in the development of a country. According to Fida (2008) SMEs contribute to economic development in various ways: by creating employment for rural and urban labor force, providing desirable sustainability, and innovation in the economy as a whole. In addition to that, large number of people relies on the small and medium enterprises directly or indirectly. Cook and Nixson (2000) also gave arguments in favor of SMEs according to him the growth of SMEs is seen as the way to accelerating the accomplishment of wider socio-economic objectives, including poverty mitigation. The growth and efficiency of small enterprises have also become famous (Mazumdar, 1997). Using the case of Northern Italy, Piore and Sabel (1984) have argued that small enterprises are more efficient because they have adopted a flexible specialization approach. In the same way, there has been growing interest in whether this model has or can be replicated in developing countries (Schmitz, 1989; Pederson, 1994; Schmitz and Musyck, 1994; Schmitz, 1995). Considerable attention has been paid in the last decade to the problem of poverty-reduction in developing countries. (World Bank, 1989, 1997). It is generally agreed that the development of micro and small-scale enterprises (MSEs) can be a key ingredient in poverty-reduction (Sen, 1980 and Green et al, 2002). On the other hand, evidence shows that small-scale enterprises contribute significantly to household incomes (Liedholm et al., 1994; McPherson, 1996; Kapoor et al., 1997; Perks, 2004; McDade \& Spring, 2005). It is also globally experienced that a well-organized SME sector is favorable to rapid industrial intensification (Hill, 2001, Llyod 2002).

\section{Data Collection Methodology}

Data were collected from 100 respondent from 30 organizations by using simple random technique. A structural questionnaire was developed to get reliability of the Data. Data were analyze by using SPSS-18 version.

Everyone has certain basic needs without which life would not be possible. There is no development when the benefits of economic progress are used only by a small number of people, while the majority are being excluded (Todaro and Smith, 2003 and Kongolo, 2010). The negative effects of recent economic downturns have seriously affected the socio-economic conditions of many people worldwide. As a response to these negative conditions, it is necessary that small, medium and large entrepreneurs enhance their job creation abilities (Barakat, 2001). A well supported and enhanced small business sector is likely to continue contributing to the economic development process in the same way as large business (Abraham, 2003).

The importance of cotton can hardly be over emphasized in the economy of Pakistan. Pakistan is one of the ancient homes of cultivated cotton, 4th largest producer of cotton, the 3rd largest exporter of raw cotton and a leading exporter of yarn in the world. Pakistan is, by and large, a mono-crop economy as cotton contributes nearly 10 per cent in the agriculture GDP and a source of 60 per cent foreign exchange earnings. The value addition through cotton is 8.2 per cent in agriculture and 2 per cent in the GDP. Cotton is not only an export-earning crop but also provides raw material to local textile industry. A profound investment in the form of over1000 ginning factories, over 400 , textile mills heavily depends upon cotton. The area under cotton has increased from 2.836 million ha in 1991-92 to 2.989 million ha in 2003-04 showing a growth rate of 0.43 per cent over the period. The production jumped from 1.1 million bales in the year 1947 to 12.8 million bales in 1991-92. Since then cotton production is swinging between 8 million bales to 11.2 million bales with an annual average of 9.5 million bales. The global Economic scenario is set for change under the free trade regime. Pakistan has signed the WTO and will enter in free trade era with the dawn of year 2005. The WTO has set many clauses under its various agreements like the Agreement on Agriculture (AOA), the Trade Related Intellectual Property Rights (TRIPS) and Sanitary and Phyto Sanitary (SPS) etc. 
Cotton along with its products is the biggest foreign exchange earner for Pakistan and is more likely to be affected through WTO regulations. This requires a profound change in the economic policies to maintain a stable share of raw cotton and its product in world market in coming scenario. In view of the importance of this silver fibre in the economy of Pakistan, authors conducted a study to estimate its competitiveness and comparative advantage in both current and future scenario. In the static analysis, the cost of production (COP) data of cotton were collected from Agricultural Prices Commission (APCom) for the three year period from 2000-01 to 2002-03. The average financial budget of cotton was developed using the three year average of COP data and market prices of seed cotton. The social budget of cotton was developed using the economic prices of cotton and inputs. The economic or export parity price(EPP) of cotton was estimated by taking the three year average price of CIF North-Europe cotton as Pakistan exports most of cotton to this region. From the fertilizers the import parity price (IPP) of DAP and Murate of Potash were estimated. The IPP of urea was not estimated as urea was not imported in the country in the bulk quantity during the study period. The IPP of DAP and Potash was prepared on the basis of f.o.b. price (ex-USA) and by considering all handling, transportation, marketing charges on the part on the way to farmer's fields. In the calculation of social parity prices, shadow exchange rate (SER) was utilized instead of official exchange rate (OER). The tradable inputs which are not measured at import parity prices, all are weighted by SER to express their opportunity cost. In the past, cotton production and marketing was subjected to many public policy interventions. The Cotton Export Corporation was phased out and cotton economy was freed in the 1990's. With the advent of trade liberalization, most of interventions have declined. The support price policy is notional and the Trading Corporation of Pakistan (TCP) is kept as third buyer in order to avoid price crash due to cartelization of powerful syndicates especially during the bumper crop. But the TCP works as a sleeping buyer.

\section{Development Experience and Changing Character of the Economy}

The development experience of Pakistan has been similar to that of market oriented developing counties. In earlier years, a significant proportion of its gross domestic product (GDP) was accounted for by the agriculture sector. But the structure of Pakistan economy has shown noteworthy changes in last five decades and now it has become more industrialized. The share of agriculture has steadily declined and in contrast there has been a rise in the share of industrial sector in composition of country's GDP. For example, in 1949, the agriculture sector accounted for $60 \%$ of GDP while manufacturing, mining and quarrying, public administration and defence, wholesale and retail trade accounted for $6 \%, 0.11 \%, 4 \%$, and $11 \%$, respectively. A perceptible drift towards transformation of the economy emerged during last five decades. Among the low-income countries, Pakistan is listed in the "three top growth performer "i.e. Sri lanka, China, Pakistan (Husain, I., 1999).

If we compare Pakistan's development experiences with other developing countries having the same income level, Pakistan was not only late in developing, its industrial sector but also late to reap the fruits of liberalized trade conditions after World War II. The main exports of the country were primary commodities. Until 1960, Pakistan Industrial Development Corporation (PIDC) set up many state enterprises, which were producing a wide range of manufacturing goods. However, unfortunately, inefficiency and corruption of management in state enterprises led to significant losses. Furthermore, private investors were hesitant to invest in those sectors where state enterprises had invested to avoid competition. Private investment is only witnessed in small scale production like rice and saw milling, Cotton and weaving apparel, and household handicrafts (Khan, 1999).

It was in the 1960s when Pakistan changed policy of industrialization via state enterprises. Reduction in direct involvement in the manufacturing sector and a supportive role of state for private investment can be seen in the second five-year plan (1960-65). The government relinquished its control over import prices, and industrial investments and in addition to this incentives were granted to private investment. During 1960s rapid investment was observed due to investment in import substituting industries like fertilizer, cement, edible oil, chemicals, machines and tool industries. The inflow of Foreign Direct Investment (FDI) was stimulated and the modern industrial sector was created.

$<$ Insert Table 1 Here $>$

$<$ Insert Table 2 Here $>$

In contrast to the 1970s, economic growth during the 1980s was accelerated and the economy obtained impressive growth rates except in 1983, when the economy grew by only $3 \%$. Meanwhile, economy also had undergone one of the strongest retrieval with the growth rate reaching $10 \%$ in 1982, the highest in two decades (Hassan, 1999). Various factors were responsible for the reversal of economic trend.

Firstly, the decrease in oil prices since 1982 benefited the country critically, reducing the trade deficit sizably and therefore helping to moderate foreign borrowing. Manufacturing industries also benefited from large cost 
reduction from lower energy prices while consumer purchasing power increased due to better terms of trade as a result of the reduction of oil prices.

Secondly, the depreciation of Pakistani rupee due to adoption of Managed Floated Exchange Rate System in 1982 helped export-oriented industries. The exchange rate policy helped to open up the global market to local industries. Exports started to pick up rapidly, growing at around 25\% in 1980, 28\% in1986 and 30\% in1990 (Ibid).

Thirdly, the recovery of various commodity prices also contributed to rapid growth in agriculture and industrial sectors which were stagnant during 1970s. This recovery in both sectors increased the purchasing power of the masses.

It is clear from the above discussion that global economic trends have had a noteworthy effect on the economy of Pakistan. In the early 1980s prolonged recession in developed market economies, increased energy prices, high interest rates and depressed commodity prices led to a slowdown of the economy. These global economic trends also affected domestic economic stability in term of increase trade, current account deficit and debt-servicing burden, higher rates of inflation, larger government fiscal deficits, and instability in domestic financial market as interest rate increased. However, in response to the turnaround of world economic trend in later half of $1980 \mathrm{~s}$, Pakistan's economy observed high growth rates.

In spite of favourable economic trends of global market, the government adopted several measures to contribute to the upturn of domestic market in the 1980s. Among others, the adoption of more flexible management of exchange rate and the devaluation of rupee was distinctly beneficial to continued export expansion. Moreover, the increased inflow of workers remittances earned the necessary foreign exchange to finance industrial development and resource-based industries, availability of low cost labour for the development of labour-intensive industries and the stable economic environment made possible by sensible management.

Table 3 also indicates the performance of economy overall and sector wise since 1990 up to 2005. The examination of data shows that the growth rate of GDP of Pakistan throughout the period under study has been inconsistent. This inconsistency in the growth rate of GDP is because Pakistan's economy still has a large agriculture component. Moreover Pakistan's Cotton sector was developed due to agriculture nature of economy. Cotton is a major component of the manufacturing sector, which depends on cotton production. If the production of cotton is good, it further leads to grow manufacturing sector. This dominance of the agricultural sector is reflected in the table as well. For example, the years when the performance of the agriculture sector was very poor, the performance of industrial and services sectors were also poor. The examination of data presented in below table clearly show interdependence of industrial and services sectors over the agriculture. At the aggregate level, the composition of country's GDP shows the same trends.

$<$ Insert Table 3 Here $>$

It seems that the frequent changes in government policies arising from the changes in government these years affected the performance of the economy adversely. Among others, not only weather unpredictability, pests, disease, and other natural disaster harm crops production but also inconsistent agriculture policies of government made it worse. Due to such a considerable share of agriculture in the economy, agriculture production is highly correlated to Pakistan's overall economic performance (Ali and Bari, 2000). When the agriculture sector has performed well, the GDP has been elevated and vice versa. Agriculture sector supplies raw material for the Cotton sector as well for sugar mill. Agriculture is not only important for its contribution to GDP but due to its forward linkage effect. However, at the aggregate level the performance of the economy seems not to be so bleak. During the period under study the economy grew on average greater than $5 \%$ as the data reflects. Even today, the agricultural sector is the major contributor in the economy accounting for $25 \%$ of the GDP, absorbing more than half of country's total labour force and providing more than $70 \%$ of country's foreign exchange earnings.

Similarly, Table 4 shows the composition of country's GDP and the share of major sectors in its composition. As discussed above, the agriculture sector provides a lion's share in the composition of GDP accounting for more than $25 \%$ of total GDP. While the share of industrial sectors is around $18 \%$, the services sectors account for $53 \%$ in 2005. However, the examination of data reflects the declining share of the agriculture in the country's GDP, while the share of industry seems to be stagnant. On the other hand, the services sectors are gaining the losing share of the agricultural sector.

$<$ Insert Table 4 Here $>$

On the basis of the above facts, we may conclude that Pakistan's development experience has been remarkable. Its economic record measured both in terms of growth rates and increase in per capita income despite a quadruple increase in population shows encouraging trends. A good structural transformation in the structure of the economy 
has taken place from the predominantly agrarian to a more diversified production structure. The country's integration with the international economy has been fairly rapid and the positive effects of adoption of liberalization and deregulation policies have been pouring in.

\section{The Evolution of Economic Development Policies of Pakistan}

In the early years, country's economic policy was shaped according to the immediate needs of the economy. Key aspects of economic policy were expansion of industrial base, establishment of institution, infrastructure building and provide extra protection to infant industries. But the excessive protection to industry severely harmed market economy by distorted economic incentives for both agriculture and industrial sectors. Moreover, the policy regime was branded by an excessive dependence on economic controls in the form of industrial licensing, administered prices and other regulations.

During the first half of 1950s, government adapted pro-industrial policy and neglected the agriculture sector. Subsequently, low growth rate of agriculture not only exposed the flaws of economic policy but shortage of food emerged. In the later half of 1950s government began to pay more attention on the development of agriculture sector to rectify these problems. Government announced a thorough strategy for development of agriculture sector in 1956.The key points of new policy were to provide fertilizer at subsidies rate, to distribute better seeds, pest control scheme, and control of salinity and water-logging. However, these policies were not properly implemented due to change of priorities in first five years plan (1955-60) and political instability.

Strict price and profit controls policy in the form of administered price and controlled profit was implemented in the early 1960s but government soon realized that this policy is weakening the incentives to expand production. To promote industrial growth government constructed number of policies like maintaining an over-valued exchange rate to guarantee the cheap availability of capital goods, and by keeping prices of agriculture inputs below to international market prices to ensure handiness of economical domestic inputs to industrial sector. Furthermore, policy of import controls and tariffs, tax holidays, and availability of loans at low rates and introduction of Export Bonus Scheme (Note 1), which subsidized manufactured goods exports through a system of vouchers (Kemal, 1978), were introduced to help industrialization drive.

As mentioned earlier that agriculture was neglected sector in 1950s but in 1960s government introduced agriculture policy aiming at self-sufficiency in food and reducing unemployment. These policies were accompanied by not only scientific and technological breakthroughs i.e. high-yielding verities of seeds (HYV), chemical fertilizers, pesticides etc., but also spread of agriculture mechanization. Due to these factors annual growth galloped to $6.4 \%$ in the second half of $1960 \mathrm{~s}$ from $2.2 \%$ in the same period of $1950 \mathrm{~s}$ (for more details please see table in appendix). Furthermore land reforms (Note 2) were also introduced in 1960s but due to administration constraints they were not implemented properly.

The 1970s witnessed socialist oriented reforms and policies. In response to growing income inequalities government not only nationalized large private manufacturing and financial institution but also introduced land reform in 1972. But the results of land reforms were not different from the previous decade mainly due to poor implementation and low amount of coverage. Government devalued the rupee in 1972 to improve the competitiveness of Pakistan's exports.

The economic policies during the 1980s accorded high preferences to the revival of confidence of private investors, which was shaken in the previous decade due to nationalization of industrial and financial institution. Government not only denationalised many public sector enterprises but also provided number of incentives to restore private investment. Furthermore, government introduced many structural reforms for the liberalization and deregulating the economy, and simplifying investment-licensing procedure. In spite of all this repair work, the response of private sector was very poor. But, by the mid of 1980 s, positive trends were witnessed and the share of private investment jumped up from $41 \%$ in $1980-81$ to $44 \%$ in $1989-90$ (Hassan, 1999).

The liberalization of agriculture market was the main objective of agriculture policy of 1980s. Especially, the government deregulated the sugar, fertilizer, and pesticide industries, removed the monopoly authority of the Rice and Cotton Export Corporations, and more importantly remove the ban on the private sector's import of edible oil (Ibid). These all measures were accompanied by the agriculture pricing policy that aimed at bring prices of inputs more in line with the market-determined prices. Further, the agriculture sector enhanced from a huge increase in bank credit as formal lending institutions, led by the Agriculture Development Bank, paid crucial concentration to solve the problem of shortage of credit in the rural area.

Managed Floating Exchange Rate (Note 3) policy was the hallmark of the 1980s. On average, due to adoption of this policy, total exports grew at a notable rate of $10 \%$ during this decade. In addition to all these policies 
government introduced reforms in much neglected sector of finance, whose performance was very poor due to excessive regulations through credit ceilings and administered interest rates. Furthermore, a series of measures in financial sector were adopted like removing distortion in financial system, minimizing interference of government in the banking system, strengthening the prudential regulations, and allowing the opening of foreign currency accounts.

Regardless of political instability and frequent change in the government during1990s, the Structural Adjustment and Stabilization Program adopted in 1988 remained intact. These programs helped economy in adjusting demand management policies and trade policies in the form of liberalization in trade, deregulation and privatisation. The major thrust of the industrial policy during 1990s was to address the structural weaknesses of industrial sector of Pakistan which were derived from import substitution industrialization and the nationalization policy of 1970s. Moreover, to improve the workability of Pakistan's industrial sector in progressively competitive global economic environment. In this regard number of measures was introduced, like tax holidays, fiscal incentives, de-licensing the investment regime and reduction of tariff on capital goods to attract private investment. Although these incentives have a significance positive impact on private investment but growth of industrial production was slow as correlate to prior decade, seemingly reflecting a delayed effect of investment on output growth.

Only one percent tax was levied on engineering, consultancy and contracting in order to increase export of services. Moreover, government not only allowed exporter to take rebate on customs duty, sales tax and surcharges through duty drawback facility but also standardized the rate of duty drawbacks as a percentage of free on board (Note 4) value of exports. In addition, other export promotion measures, like, provision of loans to exporters at low rate of interest by export finance scheme, and financial assistance to exporters seeking quality certification in respect of ISO 9000 and 14000 series certification, were taken. To attract foreign direct investment, in the export sector, export-processing zones were established at Lahore and Karachi.

In the opening year of 21 st century, government introduced two measures in the area of foreign trade: firstly, to explore new markets and diversify trade and, secondly, to reduce imports. Through trade diversification explored new markets for its exports. As a result of the policy, Pakistan's exports to Indonesia went up 161\%; China by 75\%; the UAE and Saudi Arabia by 25\%; Bangladesh by 20\%; and Korea and Australia by 9\% (Ministry of Commerce, 2001). All other countries except UAE and Saudi Arabia were the non-traditional markets in the context of Pakistan's previous export pattern. Moreover, Pakistan made serious efforts to introduce its exports in the markets, like, Kenya, Nigeria, and Syria.

The maximum trade tariffs were reduced from $30 \%$ to $25 \%$ on June 30, 2002 with regard to trade liberalization. Moreover, government established three tariff categories with duty rates of 25\%, 15\%, and 5\%. Thirty items were banned on health, religion, security and environment grounds, and high duties ranging $80 \%$ to $200 \%$ faced by automobile industry (Ministry of Commerce, 2002). Table 5 presents the country's total exports, imports and balance of trade over the last fifteen years. It also shows the ratio of countries to its imports and the ratio of country's trade deficit with that of country's GDP. These ratios help us to gauge the relationship between country's overall economic development and its effects on the country's overall foreign trade. The examination of data shows that on average, the performance of exports remained comparatively good in the first half of the decade when export grew at the average rate of about $6 \%$ per annum. But in contrast, it grew at the average rate of only $3.5 \%$ per annum in the later half of the 1990s. Similarly, annual average rate of growth of imports in the first half was $9 \%$ and declined to $2 \%$ in the later half of the decade. This slump both in exports and imports was mainly due to the various sanctions imposed by the developed countries due to the nuclear test of Pakistan and due to slump in economic activity to some extent. Similar trends are visible in the country's trade deficits. For example, trade deficit touched its peaked amounting to around US\$ 3 billion in 1996-97, and then decreased until 2002/2003 and then rose to more than US\$ 5 billion in the year 2004/2005. This increase in trade deficit was mainly due to the higher increase in imports as compared to exports as is evident from Table 5.

$<$ Insert Table 5 Here $>$

It is obvious from the above discussion that the economic structure of Pakistan has witnessed a massive transformation over the years. As we discussed earlier that there is a strong positive correlation between a country's economic development and the evolution of country's composition of foreign trade. This correlation is evident from the examination of Pakistan's trade statistics of foreign trade. Accordingly, Table 5 shows the country's classification of exports over the period under review.

Table 6 illustrates positive trends of structural changes accrued in the exports of Pakistan over the years. These trends seem to be in accordance with the country's economic development as discussed above. As a result there has been steady and considerable decrease in the share of primary commodities and semi-manufactures. On the 
contrary, the share of manufactured exports increased considered over the years. For example, as data shows, share of the primary commodities and semi manufactures declined from $32 \%$ and $24 \%$ to $16 \%$ and $22 \%$ between $1969 / 70$ and $1995 / 96$ and further to $10 \%$ each of the country's total exports. On the other hand, the share of manufactures goods increased from $44 \%$ to $62 \%$ and further $80 \%$ during the same period.

$<$ Insert Table 6 Here $>$

\section{Significance of the Cotton Sector in the Economy}

The purpose of this section is just to provide an overview and the role of the Cotton industry in the economy of Pakistan. However, next chapter will be devoted to examine the various aspects of Pakistan's Cotton industry both within the domestic and international context.

The Cotton sector -being the largest sector of the economy- has been playing an important role in the national economy of Pakistan since the independence. Even today, it is the country's most important and prime sector. Its share in the economy, in terms of contribution to GDP, employment, investment, to value added industry, exports and foreign exchange earnings is remarkable. The large contribution of the Cotton industry in the country's national economy makes it the single largest determinant of growth in the manufacturing sector. The Cotton industry contributes around $46 \%$ of the overall manufacturing activities, $31 \%$ of total investment and $35 \%$ of country's labour force is related to this sector. Similarly, the share of the Cotton in the country's total exports is as high as around $60 \%$ as is evident from the Figure 1.

\section{$<$ Insert Figure 1 Here $>$}

The examination of data shows that, over the years, Pakistan has emerged as a major supplier of cotton Cotton in the world markets. Pakistan contributes around $31 \%$ market share in world yarn trade and $8 \%$ share in cloth. In the apparel, however, it is a new entrant. Its share is low around $1 \%$ in world trade of apparel (PES, 2004-05).

\section{Scope and Limitations}

Next only to food, Cotton products are basic human requirements. The Cotton industry in Pakistan has been the most important sector playing a pivotal role in the national economy. Its contribution is unparalleled in the economy, in terms of GDP, exports, employment, Foreign Exchange Earnings (FEEs), investment and contribution to the value-added industry. It is the single largest determinant of growth in manufacturing sector. The sector is based mostly on the domestic availability of raw materials in abundance. The industry provides the largest employment ( $38 \%$ of total employment). It is the major contributory sector in earning the foreign exchange for the country. Its contribution in the FEEs is around $70 \%$ of total exports, $46 \%$ of total manufacturing, $8.5 \%$ of total GDP, $31 \%$ of total investment and $12 \%$ of total capitalization. Over the years, Pakistan has emerged as major suppliers of cotton Cotton in the world markets with a $31 \%$ market share in world yarn trade and $8 \%$ share in cloth (www.aptma.org.pk). In the apparel, however, it is a new entrant with a low share (around $1 \%$ ) in world trade of apparel.

This research endeavours to investigate the trade implications for Pakistan in the world market after implementation of WTO. The research focuses on the investigation of opportunities and threats for Pakistan in view of globalisation. However, the scope of the research is limited with a few limitations. Firstly, at the disaggregate level, Pakistan's trade relations with major economies are discussed with limited Cotton items in view. Secondly, there are some countries which have not been discussed because of their limited share in Cotton trade with Pakistan. The Cotton items selected for the study are those with a minimum of $2 \%$ market share in the total Cotton trade of Pakistan. The major markets examined are United Kingdom, Germany, Italy, France, Spain, The Netherlands, Belgium, USA and China. These countries are the leading consumers of Pakistan's Cotton and, in consequence, the leading importers. Besides these selected countries, attention is also paid to main developments in the countries, especially to Turkey, India, China, Hungary, Poland and the Czech Republic who seem to be Pakistan's major competitors in the world market by producing and exporting the same product mix.

More importantly, the EU is the major trading partner of Pakistan and as of $1^{\text {st }}$ of January 1999, the Euro (€) has become the legal currency within eleven EU member states: Austria, Belgium, Finland, France, Germany, Italy, Ireland, Luxembourg, the Netherlands, Spain, and Portugal. Greece became the 12th member state to adopt the Euro on January 1, 2001. In 2002 circulation of Euro coins and banknotes replaced national currency in these countries. Denmark, United Kingdom and Sweden have decided not to participate in the Euro. The most recent Eurostat trade statistics quoted in this study are from the year 2001. In this research, the $€$ is the basic currency unit used to indicate the value of exports and imports with EU and US \$ for the rest of the world. The collection of data regarding trade flows has become more difficult since the establishment of the single market on 1 January 1993. Until that date, trade was registered by means of compulsory Customs procedures at border crossings, but, since 
the removal of the intra-EU borders, this is no longer the case. Statistical bodies like Eurostat can no longer depend on the automatic generation of trade figures. In the case of intra-EU trade, statistical reporting is only compulsory for exporting and importing firms whose trade exceeds a certain annual value. As a consequence, although figures for trade between the EU and the rest of the world are accurately represented, trade within the EU is generally underestimated. Not only are the figures a little less accurate, but trade statistics also does not tell about the country of origin of a product when imported from an EU country. Many products originated in countries outside the EU are exported to an EU country via another EU country. This fact will most likely result in too-low figures for individual EU countries' imports from developing countries including Pakistan.

The most difficult thing faced in the study remained the collection of data from Pakistan. It was a big challenge to find out the data for the most recent years as well as those for before 1971. Shared information of East (now Bangladesh) and West Pakistan also created uncertainty. As there are only few sources at government level to provide such information, hence I relied on private sources. Furthermore, the information used in this study is obtained from a variety of different sources. Therefore, extreme care must be taken in the qualitative use and interpretation of quantitative data, both in the summary and throughout the text.

\section{Product Characteristics}

There is a huge variety of Cotton products used now-a-days in the world. Pakistan is producing most of the Cotton products and is exporting most of them. The Cotton industry of Pakistan can be classified into cotton Cotton industry, chemical/man-made fibre, woven Cotton industry and Cotton made-ups and clothing industry. These products further can be divided into many products. Figure 2 gives a breakdown of Cotton cluster while a brief product detail is give below.

$<$ Insert Figure 2 Here $>$

\subsection{Cotton industry}

Cotton is considered the largest revenue-earning crop in the world. Cotton is a natural vegetable fibre used primarily as a raw material for cloth. Cotton's strength, absorbency, and capacity to be washed and dyed also make it adaptable to a considerable variety of Cotton products. It grows best in tropical and warm subtropical latitudes. Cotton is the most used Cotton fibre in the world. Its current market share is 56 percent in all the fibres used for apparel and home furnishings. It is also widely used in non-woven Cotton and personal care items.

\subsection{Chemical/manmade fibre}

Greater portion of the global fabric trade is comprised of the manmade woven fabric. This fabric is manufactured from various manmade filaments and fibres including polyester, nylon, acrylic and viscose etc. The applications of such fabrics is not limited to industrial use only, it is also used to manufacture winter clothing, women garments and sports gear.

\subsection{Woven fabric Cotton}

The woven fabric segment of Cotton is not limited to cotton fabrics alone. With the passage of time, a wide variety of different fibres have been artificially developed which can be blended with cotton in different proportions to give certain character to the cloth, depending upon its end use. Similarly a diverse range of synthetic and artificial filaments also contribute significantly in the global production of fabric. Broadly fabric can be classified into two groups, firstly, cotton and blends and secondly, synthetic and artificial.

\subsection{Cotton made-ups and clothing industry}

Cotton made-ups and clothing sectors are very huge and they include both household Cotton products (blankets, bed linen, bath linen, kitchen linen etc) and furnishing Cotton (window covering, bedspreads and other furnishing Cotton like decorative pillowcases, throw rugs etc) as well as clothing industry that includes every kind of garments.

\section{Sources of Information}

The following sources of information with respect to data collection (otherwise referred where appropriate) have mainly been used with thanks in this research:

- Government of Pakistan, Export Promotion Bureau of Pakistan (various issues)

- All Pakistan Cotton Mills Association (APTMA) www.aptma.org.pk

- Cotton Central Research Institute (CCRI) Multan

- WTO official web site www.wto.org. 
- South Asian Association for Regional Cooperation (SAARC)

- World Development Report (1985)

- General Agreement on Tariffs and Trade (GATT) (1994)

- Monthly Management Accountant December 2004.

\section{References}

Abraham D. (2003). Local Economic Development (LED) in SouthAfrica: A useful tool for sustainable development. Urban Forum, 14:185-200. http://dx.doi.org/10.1007/s12132-003-0010-0

Azeni, S. (1998). Entrepreneurship and Job Creation. Questia Journal Article, OECD Observer, Vol. a.

Barakat NY. (2001). The role of small and medium enterprises in the economy. Jordan Times, Thursday, October 1.

DTI. (2002). Small business development guide. Department of Trade and Industry, Government Printer, Pretoria, South Africa.

DTI. (2004). Annual review of SMEs in South Africa. Department of Trade and Industry, Government Printer, Pretoria, South Africa.

Iqbal, M.S., Shaikh, F.M., Mahmood, B. and Shafiq, K. (2010). Development of Textile Industrial Clusters in Pakistan. Asian Social Science, Vol. 6, No. 11, November, p. 132.

Kongolo, M. (2010). Job creation versus job shedding and the role of SMEs in economic development. African Journal of Business Management, Vol. 4(11), pp. 2288-2295.

Todaro MP and Smith SC. (2003). Economic development (8th ed.). Pearson.

Notes

Note 1. This Bonus Voucher often carried a high premium in the market as were automatically issued against the voucher. More than $80 \%$ of the local export subsidies import licenses were accounted for this scheme.

Note 2. Land Reforms determine the ceiling of landholdings (Land Reforms of 1960 prescribed ceiling of landholdings at 500 acres of irrigated and 1000 acres of non-irrigated land)

Note 3. Manage Floating exchange Rate is the system under which a country's exchange rate is not pegged, but the monetary authorities try to manage it rather than leaving it to be set by the market.

Note 4. The value of exports when they are placed on a ship, lorry or aeroplane to leave a country.

Table 1. Share of Textiles in Employment

\begin{tabular}{|l|c|}
\hline Sub-sector & Number of peoples \\
\hline Ginning & 10,000 \\
\hline Spinning & 201,152 \\
\hline Weaving & 294,213 \\
\hline Knitting & 47,221 \\
\hline Processing and Finishing & 61,206 \\
\hline Stitching & 734,805 \\
\hline Total & $1,348,597$ \\
\hline
\end{tabular}

Source: Iqbal et al (2010) Development of Textile Industrial Clusters in Pakistan.

Table 2. Textile Industry's Economic Contribution

\begin{tabular}{|l|l|}
\hline Exports & $54 \%$ of Total Exports (US \$ 9.57Billion) \\
\hline Manufacturing & $46 \%$ of Total Manufacturing \\
\hline Employment & $38 \%$ of Total Labor Force \\
\hline GDP & $8.5 \%$ of Total GDP \\
\hline Investment & US \$ 7.0 Billion \\
\hline Market Capitalization (Listed Companies) & $5.0 \%$ of Total Market Capitalization \\
\hline
\end{tabular}

Source: Pakistan Economic Survey, SBP, TDAP and APTMA, 2010 
Table 3. Growth Rates of GDP and its Components

\begin{tabular}{|c|c|c|c|c|c|}
\hline \multirow[b]{2}{*}{ Year } & \multicolumn{3}{|c|}{ Commodity Producing } & \multirow{2}{*}{$\begin{array}{c}\text { Services } \\
\text { sector }\end{array}$} & \multirow[b]{2}{*}{ GDP \% } \\
\hline & Agriculture & $\begin{array}{l}\text { Mining \& } \\
\text { Quarrying }\end{array}$ & Manufacturing & & \\
\hline $1949-60$ & 1.7 & 10.4 & 7.8 & 3.9 & 3.1 \\
\hline $1960-70$ & 5.1 & 8.5 & 9.9 & 7.5 & 6.8 \\
\hline $1970-77$ & 1.6 & 4.2 & 3.8 & 5.9 & 4 \\
\hline $1977-82$ & 4 & 8.3 & 10.6 & 7.4 & 6.8 \\
\hline $1982-88$ & 3.8 & 10.5 & 7.6 & 7.5 & 6.5 \\
\hline $1988-90$ & 4.1 & 10.1 & 7.9 & 7.4 & 6.5 \\
\hline $1990-95$ & 4.84 & 4 & 5.54 & 5.2 & 5.18 \\
\hline 1995-99 & 3.76 & 4.4 & 2.02 & 4.85 & 4.71 \\
\hline 1999-00 & 6.09 & 3.67 & 1.53 & 4.15 & 3.91 \\
\hline $2000-01$ & -2.2 & 0.5 & 9.3 & 3.1 & 1.8 \\
\hline 2001-02 & 0.12 & 1.3 & 5.5 & 4.8 & 3.12 \\
\hline $2002-03$ & 4.09 & 4.9 & 6.91 & 5.3 & 5.13 \\
\hline 2003-04 & 2.2 & 6.9 & 14.1 & 6 & 6.44 \\
\hline 2004-05 p & 7.6 & 8.9 & 12.5 & 7.9 & 8.23 \\
\hline
\end{tabular}

Source: Economic Survey of Pakistan, Various Issues

Note: services include construction, electricity and gas, trade, transport, finance and insurance, ownership and dwelling, public administration and defence and 'other' services.

Table 4. Distribution of Sectoral Share in GDP (\%age)

\begin{tabular}{|c|c|c|c|c|c|}
\hline Years & Agriculture & Manufacturing & Services & Others & Total \\
\hline $1949-50$ & 53.2 & 7.8 & 25.15 & 13.85 & 100 \\
\hline $1959-60$ & 45.8 & 12 & 35.21 & 6.99 & 100 \\
\hline $1969-70$ & 38.9 & 16 & 40.2 & 4.9 & 100 \\
\hline $1979-80$ & 30.6 & 17 & 45.04 & 7.36 & 100 \\
\hline $1990-91$ & 25.68 & 17.71 & 48.45 & 8.16 & 100 \\
\hline $1994-95$ & 24.65 & 18.17 & 48.77 & 8.41 & 100 \\
\hline $1999-00$ & 25.93 & 16.69 & 49.06 & 8.32 & 100 \\
\hline $2000-01$ & 25.1 & 15.9 & 51.8 & 7.2 & 100 \\
\hline $2001-02$ & 24.4 & 16.1 & 52.7 & 6.8 & 100 \\
\hline $2002-03$ & 24.2 & 16.4 & 52.9 & 6.5 & 100 \\
\hline $2003-04$ & 23.3 & 17.6 & 52.6 & 6.5 & 100 \\
\hline $2004-05$ & $23.10 \mathrm{p}$ & $18.30 \mathrm{p}$ & $52.40 \mathrm{p}$ & 6.2 & \\
\hline
\end{tabular}

Source: Economic Survey of Pakistan, Various Issues 
Table 5. Pakistan's Exports, Imports and Balance of Trade (In 2000-01 Prices*)

\begin{tabular}{|c|c|c|c|c|c|}
\hline Years & Total Exports & $\begin{array}{c}\text { Total } \\
\text { Imports }\end{array}$ & $\begin{array}{c}\text { Balance of } \\
\text { Trade }\end{array}$ & $\begin{array}{c}\text { Exports as \%age } \\
\text { of Imports }\end{array}$ & $\begin{array}{c}\text { Trade Deficit } \\
\text { as \%age of GDP }\end{array}$ \\
\hline $1990-91$ & 5,913 & 7,345 & $-1,432$ & 80.5 & -8.1 \\
\hline $1991-92$ & 6,502 & 8,713 & $-2,211$ & 74.6 & -10.5 \\
\hline $1992-93$ & 6,098 & 8,897 & $-2,800$ & 68.5 & -11.2 \\
\hline $1993-94$ & 6,480 & 8,157 & $-1,677$ & 79.4 & -6.1 \\
\hline $1994-95$ & 7,016 & 8,962 & $-1,946$ & 78.3 & -6 \\
\hline $1995-96$ & 7,230 & 9,802 & $-2,572$ & 73.8 & -6.6 \\
\hline $1996-97$ & 7,363 & 10,526 & $-3,163$ & 70.0 & -7.2 \\
\hline $1997-98$ & 7,449 & 8,735 & $-1,286$ & 85.3 & -2.6 \\
\hline $1998-99$ & 7,247 & 8,786 & $-1,540$ & 82.5 & -2.8 \\
\hline $1999-00$ & 7,781 & 9,361 & $-1,580$ & 83.1 & -2.6 \\
\hline $2000-01$ & 9,202 & 10,729 & $-1,527$ & 85.8 & -2.3 \\
\hline $2001-02$ & 8,875 & 10,046 & $-1,171$ & 88.3 & -1.6 \\
\hline $2002-03$ & 10,073 & 11,029 & -957 & 91.3 & -1.3 \\
\hline $2003-04$ & 10,483 & 13,275 & $-2,792$ & 79.0 & -3.4 \\
\hline $2004-05$ & 11,720 & 16,773 & $-5,053$ & 69.9 & -5.2 \\
\hline $2005-06$ & 12,627 & 21,913 & $-9,286$ & 57.6 & -8.4 \\
\hline
\end{tabular}

Source: Economic Survey of Pakistan (Various Issues).

*Average Exchange Rate During Base Year (2000-01) was 1\$=Rs.58.58.

Note: For current Prices please see table 5 in Appendix A.

Table 6. Classification of Pakistan's Exports (\%age Share in Total Exports)

\begin{tabular}{|c|c|c|c|}
\hline Years & Primary Commodities & $\begin{array}{c}\text { Semi- } \\
\text { Manufactures }\end{array}$ & $\begin{array}{c}\text { Manufactures } \\
\text { Goods }\end{array}$ \\
\hline $1969-70$ & 33 & 24 & 44 \\
\hline $1979-80$ & 42 & 15 & 53 \\
\hline $1989-90$ & 20 & 24 & 57 \\
\hline $1990-91$ & 19 & 24 & 60 \\
\hline $1991-92$ & 19 & 21 & 64 \\
\hline $1992-93$ & 15 & 21 & 66 \\
\hline $1993-94$ & 10 & 24 & 64 \\
\hline $1994-95$ & 11 & 25 & 62 \\
\hline $1995-96$ & 16 & 22 & 70 \\
\hline $1996-97$ & 11 & 21 & 70 \\
\hline $1997-98$ & 13 & 17 & 73 \\
\hline $1998-99$ & 12 & 18 & 72 \\
\hline $1999-00$ & 12 & 15 & 75 \\
\hline $2000-01$ & 13 & 15 & 78 \\
\hline $2001-02$ & 11 & 14 & 78 \\
\hline $2002-03$ & 11 & 11 & 80 \\
\hline $2003-04$ & 10 & 12 & 10 \\
\hline $2004-05$ & 10 & & \\
\hline
\end{tabular}

Source: Economic Survey of Pakistan, various issues. 


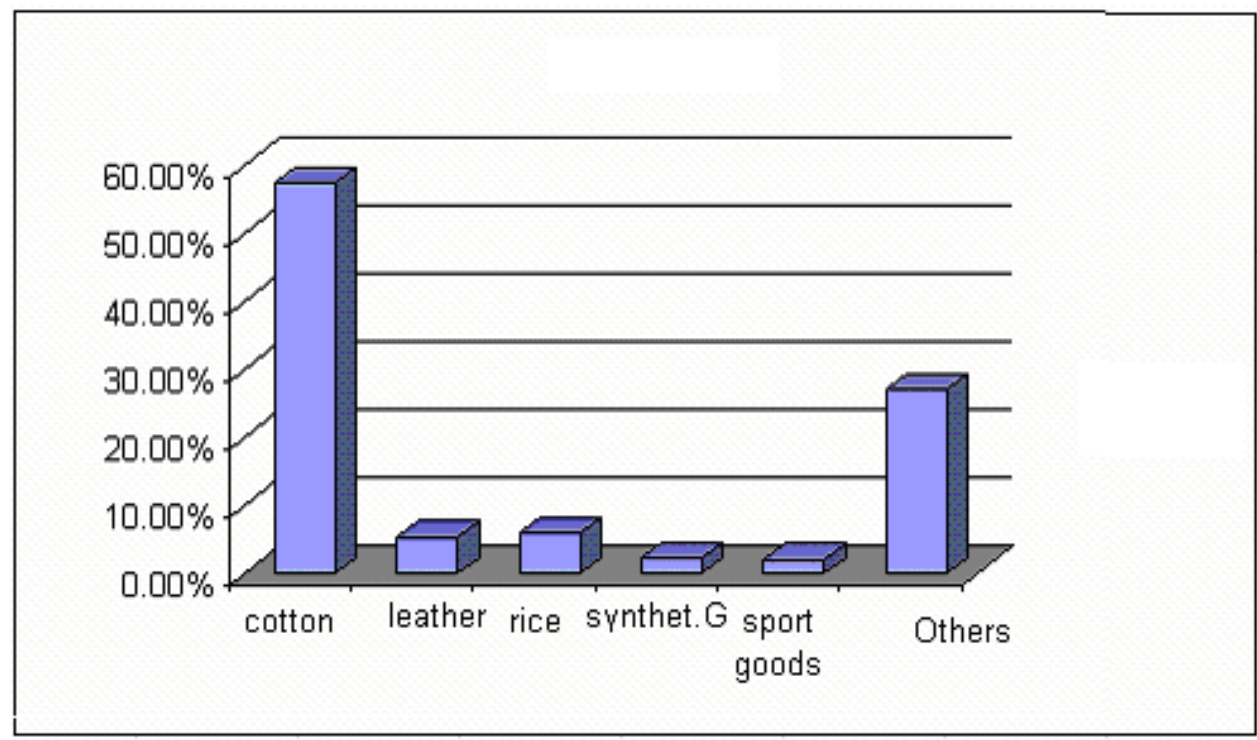

Figure 1. Pakistan's Major Exports (2004-05)

Source: Economic Survey of Pakistan, 2004-05

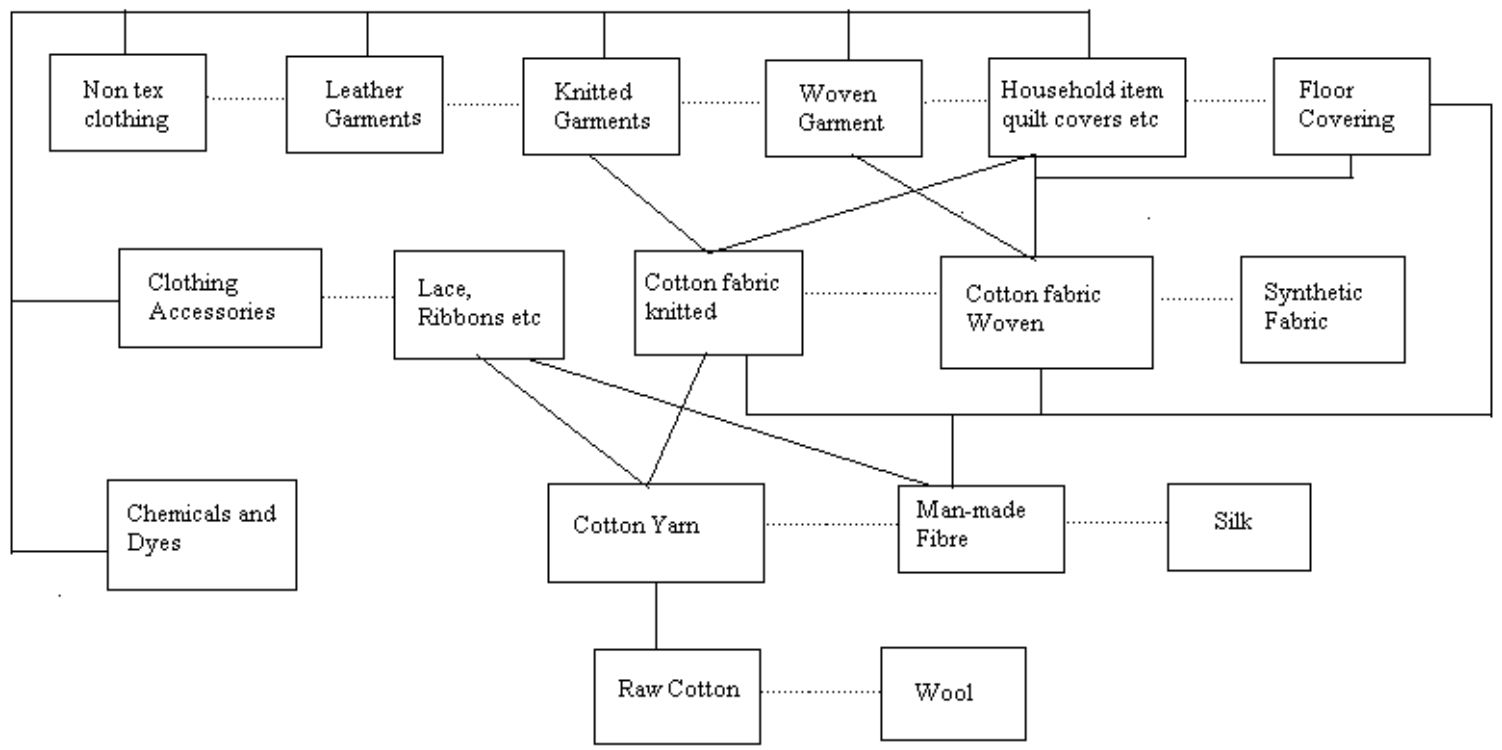

Figure 2. The Textile based Cotton/clothing cluster - Pakistan

Source: Bari (2003), p.112

Key ......... related industries supplier industries 